The International Economy, Vol. 23, 2020

\title{
Introduction to the Special Issue in Memory of Michihiro Ohyama and Makoto Ikema
}

\author{
Taiji Furusawa $^{1)}$ and Yoshimasa Shirai ${ }^{2)}$ \\ ${ }^{1)}$ Graduate School of Economics, University of Tokyo \\ ${ }^{2)}$ Faculty of Economics, Keio University
}

Michihiro Ohyama and Makoto Ikema, life-time close friends, had been the leading scholars in the field of international trade in Japan for many years until their passing in 2017. They had made significant contributions to the economics literature, assisted the governments in designing economic policies, and helped the advancements of the Japan Society of International Economics (JSIE) as well as other academic associations. Both served the JSIE as the president, Makoto Ikema in 1998-2000, and Michihiro Ohyama in 2002-2004. Their influences to both the academics and the public persist even more widely now, as their students, many of whom have become researchers in international trade and other fields of economics, follow and lead the paths they paved.

Michihiro Ohyama earned his Ph. D. in economics at University of Rochester in 1972. Greatly influenced by Ronald Jones and Lionel McKenzie, he started his research career working on international trade and general equilibrium theory. Perhaps his most influential paper is "Trade and Welfare in General Equilibrium" published in Keio Economic Studies. It showed the existence of the custom union tariff rates under which even with the formation of custom union the member countries can maintain pre-union level of international trade with nonmember countries. This result is known as the Ohyama-Kemp-Wan Theorem and is frequently cited in the literature of international trade. As he continued his research career at his alma mater, Keio University, he widened his research area to international finance, macroeconomics, industrial organization and others. Part of his works covering a wide variety of research topics are collected in Ohyama (2016).

Makoto Ikema had published numerous papers on various topics, such as economic growth and trade, regional trade arrangements, and international oligopoly. One of his papers, entitled "The Effect of Economic Growth on the Demand for Imports: A Simple Diagram", published in Oxford Economic Papers in 1969 unveiled how a country's economic growth affects other countries, and has been referred to later as the Hicks-Ikema Theorem. His contribution to the analysis of international oligopoly by proposing a useful analytical tool, called the Cournot-Ikema Curve, is also noteworthy (Ikema, 1990, 1991). He has also written many topical policy papers, which have affected public opinions.

This special issue of The International Economy is a tribute to our teachers Michihiro Ohyama and Makoto Ikema. This issue is a collection of the papers that are written by their former students, whom they had formally or informally advised and encouraged to engage in research with kindness and warmness.

In the first paper, Noriyuki Yanagawa theoretically explores the role of financial market imperfection played in the organizational choice of firms - an "integration" of a manufacturing plant in the South to the North headquarter or an "outsourcing" of manufacturing plant ser- 
Introduction to the Special Issue in Memory of Michihiro Ohyama and Makoto Ikema

vice to the South. He extends the model of Antràs and Helpman (2004) in a manner that a fixed setup cost for manufacturing in the South must be financed in an imperfect financial market. If the degree of imperfection is low, then the middle productivity firms choose integration while the high productivity firms choose outsourcing - a result consistent with that of Antràs and Helpman. But if the degree of imperfection is high, then the middle productivity firms choose outsourcing while the high productivity firms choose integration - a result consistent with Grossman and Helpman (2004). Thus, Yanagawa provides a financial market imperfection perspective in understanding the conflicting results observed in the literature of global outsourcing.

Next, Jota Ishikawa, Yoshimasa Komoriya, and Yoichi Sugita theoretically examine the interaction between a country's import policy and international technology licensing. They analyze this issue in the framework of international duopoly with an independent foreign licenser. Licensing the technology to either firm, domestic or foreign, adversely affects both firms, while it benefits domestic consumers. They show that the welfare-maximizing home government may choose a tariff that induces the licenser to license the technology to the foreign firm. In addition, trade liberalization may induce the licenser to switch the licensee from the home firm to the foreign. Their analysis suggests that industrial policies, such as the promotion of technology licensing, are closely related to trade policies and that the optimal policies can be much subtler than encouraging technology licensing from abroad to domestic firms.

In the third paper, Masatoshi Tsumagari theoretically explores the impact of intensified global market competition on domestic quality of life, motivated by the assertion of Ohyama (2016, Chapter 11) that an intensified competition leading to misconducts of firms is not inherent to free market transactions but rather due to market failure. On the verge of losing their business facing intensified competition, inefficient firms are incentivized to gain from selling valueless products to uninformed consumers. These misconducts destroy consumers' trust in the market, leading to the reductions in demands. To escape from these negative externalities, efficient firms undertake innovations, which build consumers' trust by raising quality of goods. Using a simple model incorporating these countering effects of misconducts and innovations on the consumers' trust, he shows conditions that intensified competition harms (or improves) average product quality, social welfare and inequalities across firms in the domestic market.

Then, Ki-Dong Lee, Kangsik Choi, and DongJoon Lee build an international oligopoly model with network externality to explain possibly different organizational forms for firms across different countries, especially when a country imposes an import tariff. In their model, tariffs make the vertical separation the dominant strategy for the foreign firm, because the vertical separation would raise the optimal tariff against its products. The domestic firm, on the other hand, chooses to be vertically separated if the network externality is sufficiently weak. Their theoretical analysis contributes not only to the strategic trade policy literature but also to the strategic delegation literature, as it shows that asymmetric choice of strategic delegation (or vertical organization) between the firms naturally arises in an international setting where countries adopt different trade policies so that firms in different countries are differentially affected by the governments' policies.

Motivated by Ohyama (1997), Akihiko Yanase theoretically examines the international 


\section{T. Furusawa and Y. Shirai}

coordination of entry policy in a monopolistic competition model of international trade. While Ohyama's model is based on a quadratic utility function over differentiated goods with a feature that love-for-variety has a direct impact on household demand, Yanase's model is deliberately made silent on this direct effect, and employs a non-homothetic quadratic utility function which generates variable markups along the line with the recent trade literature. He compares and clarifies the effects of cooperative and non-cooperative entry policies between two countries on the number and profits of firms and welfare both in short and long runs.

In the sixth paper, Tomohiro Ara and Hongyong Zhang closely examine the difference in trade elasticities between intermediate-goods trade and final-goods trade. They derive theoretically the result that the trade elasticity is greater in intermediate-goods trade than in finalgoods trade, in the context of a heterogeneous-firm, heterogeneous-country model. Then, they use Chinese Customs data to find evidence for this theoretical prediction. The key to understanding this difference is differential impacts of a change in trade costs on the extensive margins of trade. Whereas a change in trade barriers for final goods affects only entry into the final-good sector, a change in those for intermediate goods affects entry into both final-goods and intermediate-goods sectors. Their analysis helps us understand why intermediate-goods trade increases relatively more than final-goods trade in recent years.

In the seventh paper by Yoshinori Kurokawa, casting doubt on the WTO's 2004 decision in excluding the issue of interaction between competition policy and international trade from the Work Programme set out in 2001 Doha Ministerial Declaration, he theoretically and numerically examine the effects of competition policies on the skill premium (the wage difference between skilled and unskilled workers) in both home and trading partner countries. In a closed economy model, he theoretically shows that an entry deregulation can increase its skill premium while an antitrust policy (a reduction of the number of firms participating in cartel) has an opposite effect. He numerically shows that in an asymmetric, two-country model, the entry deregulation and the antitrust policy in one country are transmitted to the partner country but with lesser degree than that on home country.

In the next paper, Hajime Kubota extends Ohyama's (1972) traditional trade model with finite number of goods to one with infinitely-many goods in an infinite-horizon model, in order to examine whether Ohyama's various results still obtain in a more general setting. Ohyama's important results include the famous Ohyama-Kemp-Wan theorem that customs union formation can always be designed to benefit all the countries, including non-member countries. Kubota successfully shows that such welfare implications of trade can be extended to a more-general dynamic model. This extension is important and reassuring, because the world we live in is dynamic by nature.

In the ninth paper, Morihiro Yomogida theoretically examines the relationship between a degree of vertical specialization and the wage inequalities in a slightly extended version of a standard monopolistic competition model of international trade. He does so by dividing the production process into an upstream blueprint creation and a downstream production, where the former uses skilled labor and the latter unskilled labor. This makes it possible to express the degrees of vertical specializations and the wage inequalities between skilled and unskilled labor in a very simple manner with fundamental parameters, such as the degree of product differentiation and the similarity index for the ratios of skilled and unskilled labor endowment between two countries. He shows that the higher the degree of product differentiation and/or 
the less similar the labor endowment ratio, the greater the share of vertical specialization and the wage inequalities.

In the next paper, Keisaku Higashida theoretically analyzes monitoring and importrestriction policies for international trade in secondhand goods and recyclable materials, both of which cause environmental and health damage in a developing country that imports those goods. Simple trade restrictions are not effective in many cases, in the presence of illegal trade, so that monitoring policies of both importing and exporting countries are important. He builds a trade model, in which a developed country exports secondhand goods, legally or illegally, or ships them as recyclable materials, and shows that among others, a stricter import restriction on legal imports increases its environmental damage if the developing countries legally imports recyclable materials and if the marginal environmental damage caused by illegal trade is more serious than that caused by legally-traded recyclable materials. His analysis sheds light on the environmental issues of international trade in recyclable but hazardous products between developed and developing countries.

In the eleventh paper, Ichiroh Daitoh examines the economic growth in the world of declining population. In a semi-endogenous growth model, the long-run growth rate of per capita output declines with the fall of population growth rate when it is positive. However, if it falls below some negative critical level, the long-run growth rate starts to increase due to the positive externalities from knowledge accumulation. He finds that this critical level of negative population growth rate is empirically relevant. He further discusses, even in the Solow model which has no externalities from knowledge accumulation, it is also possible that the growth rate of per capita output increases as population declines, if child rearing costs are introduced.

Lastly, Taiji Furusawa and Yoichi Sugita investigate whether and to what extent the growth of the emerging economies affects other countries during 1995-2007. Ikema (1969) theoretically demonstrates that a country's productivity growth normally benefits other countries, whereas Ohyama $(1998,2010)$ shows that a country's growth in terms of product quality may hurt other countries if consumer preferences exhibit home bias for quality. Furusawa and Sugita build a multi-country, multi-industry Ricardian model of global value chains, which incorporates quality home bias, and show that whether the emerging economies grew in terms of productivity or quality varies across countries; China, for example, mainly grew in productivity while Russia and India in quality. They also find from data that quality home bias exists, and that the growth of the emerging economies had only modest impacts on the welfare of other countries.

We are grateful to all the authors of the papers in this special issue. Those papers are anonymously reviewed after presented and discussed in the Workshop in Memory of Michihiro Ohyama and Makoto Ikema, held in November, 2019 at Keio University. We express our sincere gratitude to Yoshihiko Fukushima, Eiji Horiuchi, Tetsuro Ichikawa, Koji Ishibashi, Toshiyasu Izawa, Tomohiro Kuroda, Yoshihiro Mizoguchi, Yasuhiro Nakagami, Toshihiro Okubo, Naoko Shinkai, and Shumpei Takemori for discussing the papers. We would like to mention that they too are former students of Michihiro Ohyama and Makoto Ikema. We are also indebted to the JSIE for its generosity to allow us to publish this special issue in memory of Michihiro Ohyama and Makoto Ikema, our highly and forever respected advisors. 
T. Furusawa and Y. Shirai

\section{References}

Antràs, P. and E. Helpman (2004), Global Sourcing, Journal of Political Economy, 112(3), 552-580.

Grossman, G. M. and E. Helpman (2004), Managerial Incentives and the International Organization of Production, Journal of International Economics, 63, 237-262.

Ikema, M. (1969), The Effect of Economic Growth on the Demand for Imports: A Simple Diagram, Oxford Economic Papers, 21(1), 66-69.

Ikema, M. (1990), Cournot-kinkou-to-sannyu-soshi: Cournot-sen-niyoru-zukai, in Japanese (An Alternative Geometrical Representation of a Cournot Duopoly), Hitotsubashi Ronsou (Hitotsubashi Review), 103(6), 638-652.

Ikema, M. (1991), Kokusai-fukusen-kyousou-heno-riron, in Japanese (Theory of International Duopoly), Bunshindo.

Ohyama, M. (1972), Trade and Welfare in General Equilibrium, Keio Economic Studies, 9(2), 37-73. Reprinted in J. P. Neary ed., International Trade (The International Library of Critical Writing in Economics 59), An Elgar Reference Collection, 1995, 109-145.

Ohyama, M. (1997), Monopolistic Competition, Increasing Returns and International Coordination of Entry Policy, Pacific Economic Review 2, 197-209.

Ohyama, M. (1998), Hinshitsu-kaizengata-gijutsu-sinpo-to-kokusai-boueki, in Japanese, (Quality Improving Technological Progress and International Trade), Mita Gakkai Zasshi (Mita Journal of Economics), 91(3), 407-419.

Ohyama, M. (2010), Innovation and International Trade, Keio Economic Studies, 46, 1-45.

Ohyama, M. (2016), Macroeconomics, Trade, and Social Welfare, Springer, Tokyo. 